NEW NIST PUBLICATION

July 1990

\title{
TRADE IMPLICATIONS OF PROCESSES AND PRODUCTION METHODS (PPMs)
}

\section{Patrick W. Cooke}

U.S. DEPARTMENT OF COMMERCE National Institute of Standards and Tochnology Offlce of Standards Sorvices Standards Code and Information Galthersburg, MD 20899 Robert A. Mosbacher, secretary Loe Mercer, Doputy Under Socrotary for Tochnolosy NATIONAL INSTTUUTE OF STANDARDS AND TECHNOLOQY

John W. Lyone, Director

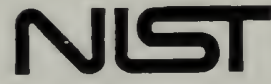





\section{TRADE IMPLICATIONS OF PROCESSES AND PRODUCTION METHODS (PPMs)}

\section{Patrick W. Cooke}

U.S. DEPARTMENT OF COMMERCE Natlonal Institute of Standards and Tochnology Offlce of Standards Services Standards Code and Information Galthersburg, MD 20899

March 1990

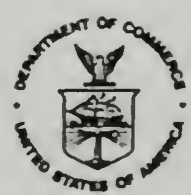

U.S. DEPARTMENT OF COMMERCE Robert A. Mosbacher, Secretary Lee Mercer, Deputy Under Secretary for Tochnolory

MATIONAL INSTIUUTE OF STANDAROS AND TECHNOLOOY

John W. Lyons, Director 



\section{Table of contents}

Page

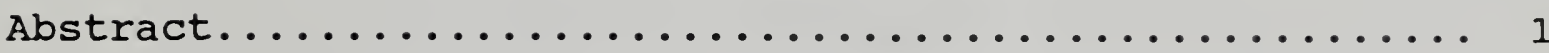

1. Introduction $\ldots \ldots \ldots \ldots \ldots \ldots \ldots \ldots \ldots \ldots \ldots$

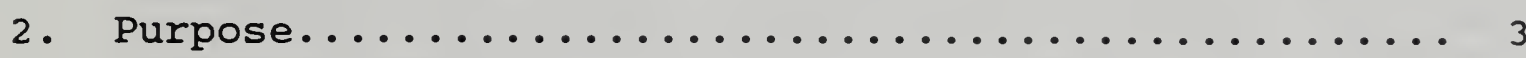

3. Background Discussion...................... 3

4. PPM's and the GATT standards code............ 5

5. Scope and Coverage.................... 6

6. Affected Manufacturing Sectors and Products....... 7

7. Examples of PPM Type standards.............. 8

8. Definitional Approaches for PPM's............ 8

9. NIST - Developed PPM Definition.............. 9

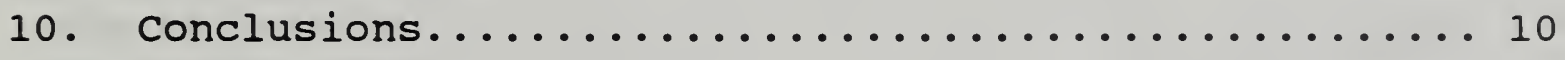

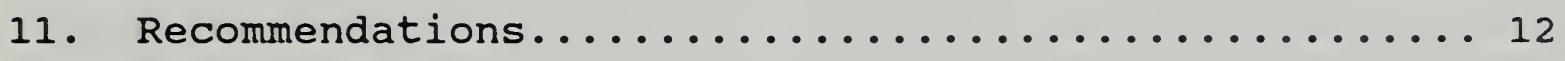

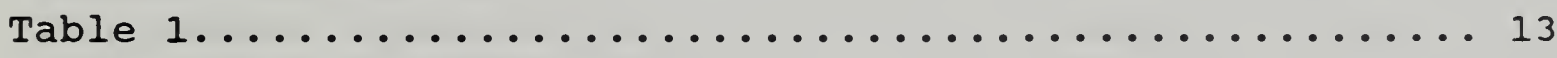

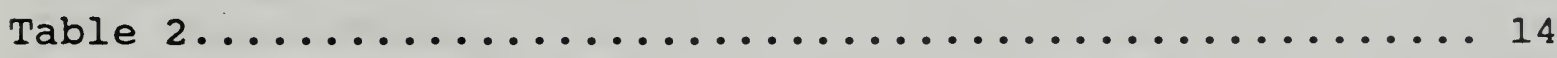

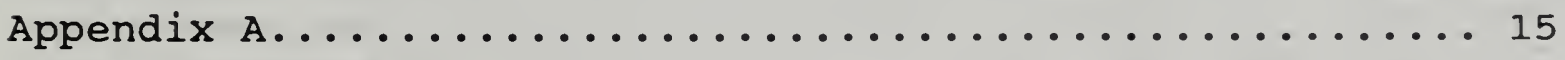

Appendix B............................... 17 



\section{Abstract}

This report discusses processes and production methods (or PPM's) and their relationship to trade, the GATT Agreement on Technical Barriers to Trade, and traditional product standards used in international commerce. The report provides background information on PPM's, a suggested definition, and the possible extension of their application from the agricultural sector to industrial products.

\section{Introduction}

In international commerce, traditional product standards and technical regulations have generally been applicable to the final product with regard to its fitness for purpose (e.g., size, shape, color, performance characteristics, etc.). This has been the case for both industrial and agricultural products. The GATT standards Code is based on the premise that standards for individual products not become technical barriers to trade. (See discussion on GATT standards code in section 4.) However, an increasingly large and growing body of technical standards and regulations prescribe the in-process or intermediate steps to be taken to produce a product, rather than the characteristics of the end-item or final product. This supplementary and possibly unfamiliar area of coverage for technical standards and/or regulations has been designated as "processes and production methods" or "PPM's." (See definition for "Process and Production Method (PPM)" and "PPM Standard" given in section 9.) There are various reasons for this relatively recent and progressing shift in coverage. The following developments in manufacturing have significantly affected standardization approaches:

- Traditional manufacturing standards emphasized post-production inspection and testing of products. A product that did not fit or work properly was rejected or reworked. This uneconomical approach has been replaced or supplemented in many industries by a process control system which directly

1 The abbreviation for this relatively unfamiliar trade term may be mistaken for at least two other uses of the abbreviation -

"ppm" (lower case), scientific terminology for "parts per million," a measure of concentration for fractional constituents, and "PPM" (upper case), the electronic communications term for "pulse-phase modulation." 
monitors and adjusts the production process to ensure that the product is correct/proper the first time, resulting in better quality and improved productivity. An increasing number of standards include such quality assurance provisions. The International organization for Standardization has established a new working group in Technical Committee 176 (on Quality Assurance) to develop general quality assurance criteria for the process industries.

The life cycles for many manufactured products and production processes - previously measured in decades - are now often less than five years. This reduction has been driven by a worldwide explosion of advancing technology that has generated about 90 percent of all current scientific knowledge in just the last 30 years. This explosion in technological development has broadened (i.e., there are now more elements to be standardized) and deepened (i.e., more details to be specified) the need for standardization. In these processintensive high technology industries, the application of PPM standards or PPM-related provisions in regulations are becoming much more prevalent, with PPM-related provisions frequently required in the determination of conformity to regulatory requirements.

In many industrialized countries, including the United states, explicit governmental regulations govern various manufacturing practices that are properly classified as a form of "processes and production methods." Examples are the "good manufacturing practices" (GMP) and "good laboratory practices" (GLP) regulations in place in the pharmaceutical, medicaldevice and food processing industries.

The past decade has seen a substantial increase in globalization of production. Multinational corporations have engaged in "outsourcing" and have developed multiproduction centers and/or joint ventures to exploit the comparative advantages (e.g., labor rates, raw materials, regulatory environment) of different countries. Increasingly, final products are made by assembling piece parts and components manufactured in or procured from a variety of different countries. This is especially true for the electronics and automotive industries. The overall assurance of conformance to standards by such a hierarchy of components and the final product itself has therefore become extremely complex.

- The increased emphasis - developed by the Japanese - on reduced or no inventory during manufacture has implications for PPMs. The "just-in-time" (JIT) production system relies on production processes capable of meeting quality requirements because little or no inventory exists in the plants to replace defective products. In order for JIT to be 
viable, manufacturers must emphasize PPM's to ensure acceptable quality levels and delivery schedules.

state-of-the-art technologies such as computer-aided manufacturing (CAM) have the potential of improving the quality of products by providing more consistent equipment operation and processing with shorter lead times than is possible with humans. These systems use real-time sensing, deterministic metrology methods, tool characterization, process-intermittent gauging, and process certification to control automated processes, such as machining.

\section{Purpose}

The purpose of this report is to review the status of PPM's with regard to the GATT standards code and to inform U.S. industrial producers to the trade implications of PPM's beyond the agricultural sector. Some illustrative examples of trade-related industrial-sector PPM's are provided in the next section; two others are given in the Appendix.

\section{Background Discussion}

Processes and production methods may take the form of technical specifications, standards and regulations. They specify the steps to be taken to produce a product rather than the characteristics of a final product (product standard). A PPM may appear as part of a definition of a product, as a voluntary standard or as a governmental regulation requiring that a product be made a certain way. Thus, a regulation banning the use of designated substances during production of a product is a PPM. In the past, PPM's have been associated primarily with the agricultural sector, but are becoming increasingly significant in the industrial sector.

PPM's are not inherently detrimental. They may, in fact, represent the current state-of-the-art or the descriptive capabilities of the developers of a standard. However, the way such standards are used may have detrimental effects on the commerce of the products or systems involved. It may be difficult to criticize the use of a PPM between a particular buyer and a particular seller. However, when such a standard is used as the sole basis for a mandatory regulation (particularly in the safety and health areas) in a particular jurisdiction, and thereby affects all sales in that geographical area, the regulation can transform a PPM standard, innocuous in itself, into an important trade barrier. The seriousness of such a barrier may be dependent on the size of the marketing area, the existence of other products that might perform the intended function implied (but not stated) in the regulation, and the number of producers involved. Singling out one PPM in a given functional area and making it a mandatory requirement in a sizable, volatile trading region can turn such a standard into a significant trade barrier. 
An example of a relatively simple PPM trade barrier can be seen in the regulations of one importing country that describes in detail the cleaning process that must be followed relative to the internal surfaces of copper tubing intended for use in potable water supply systems. Copper tubing manufacturers in the U.S. do not make use of this process and do not have the type of equipment it demands. However, the inside surfaces of such U.S. tubing are cleaned in a manner that is acceptable to U.S. health authorities. Because the U.S. cleaning process involved is not the same as the standard process made mandatory in this one particular country, clean U.S. tubing must be recleaned in that country before it can be offered for sale. The cost involved in the handling, storing and rehandling of incoming shipments to this country plus the cost of the recleaning process itself constitute a serious trade barrier problem for all foreign copper tube manufacturers.

Some examples of PPM-related provisions in the agricultural sector are:

- Food irradiation rules

- Hygienic practices

- Animal welfare restrictions (maximum number of birds per cage, minimum amount of barn space per milk-fed veal calf)

- Requirements for immersion-chilling of poultry during slaughter

- Growing conditions of plants (height above ground)

- Design of slaughtering facilities (separation of different steps of the slaughtering process)

- Prohibited use of certain inks for meat stamps

- Temperature/time specifications for cooking processed foods

- Seed production rules

In early drafts of the GATT Agreement on Technical Barriers to Trade (Standards Code) ${ }^{2}$, the United States supported full inclusion of PPMs. However, some delegations were concerned about the potential administrative burdens with respect to agricultural goods, hence the group excluded PPM's from the standards Code: it currently fully covers only industrial and agricultural standards and regulations that apply to a product's final characteristics. Processes and production methods are covered in a limited fashion under Article 14.25.

The Code's Article 14.25 (on "Processes and Production Methods") allows signatories to invoke dispute settlement procedures over

2 The General Agreement on Tariffs and Trade (GATT) is the principal multilateral agreement covering world trade. Its purpose is to foster unrestricted multilateral trade by binding participating nations to negotiate trade rules and by mandating penalties for deviations from these obligations. 
PPMs in some circumstances, but the European community (EC) and other signatories have interpreted the article so narrowly as to make it nearly impossible to resolve a case related to PPMs. Our current dispute with the EC over its hormone ban is a case in point. 3

Only with inclusion of PPMs will the GATT provide a forum to challenge questionable or arbitrary manufacturing or process requirements which create barriers to trade unjustified by real health or safety considerations.

\section{PPM's and the GATT Standards code}

Differences among nations' standards, product testing and approval procedures, and certification systems often hinder the free flow of goods in international commerce. The Agreement on Technical Barriers to Trade -- "The Standards Code" -- under the auspices of the General Agreement on Tariffs and Trade (GATT) was negotiated and concluded in 1979 as part of the Tokyo Round of Multilateral Trade Negotiations. It was the first international agreement to

3 On January 1, 1989 the EC put into effect the controversial 1985 ban on the sale of meat from cattle treated with any steroidal hormones. The ban affects over $\$ 100$ million of beef exported by the U.S. to Europe each year. This ban had implications for all beef exporters because, at acceptable levels, it is impossible to distinguish between "artificial" hormones from implants and those occurring naturally in cattle. This ban also has trade implications for U.S. pharmaceutical producers who manufacture growth hormones covered by the ban.

The EC has officially stated that the ban has its roots in health and safety concerns. However, economic reasons may have prompted this ban since it attempts to protect an EC beef market that would be disadvantaged by competitively priced beef from the United States.

The United States retaliated against this alleged non-tariff trade barrier by assessing $100 \%$ tariffs on seven food and beverage items from the EC totaling approximately $\$ 100$ million each year. After the EC threatened to counter-retaliate, both parties assembled a task force to resolve the dispute.

It is uncertain how this dispute will be resolved, but the European Commission indicates that it will continue to wage a battle against the retaliatory measures that the U.S. took against European food exports in the wake of Europe's refusal to import hormone-treated U.S. beef. 
recognize the importance of standards-related activities ${ }^{4}$ in international trade. The code went into effect on January 1, 1980 and thirty-nine countries including the United states, the EC, individual EC member states ${ }^{5}$ and the EFTA countries have signed it." Table 1 lists all the signatories to the GATT Standards Code.

The terms "voluntary standard" and "technical regulation" are often used interchangeably. However, obligations of the Standards Code relate only to mandatory standards since voluntary standards are presumed unlikely to cause obstacles to trade. By establishing a framework of common rules, the code is designed to eliminate the misuse of standards or certification systems to act as barriers to international trade. It does not attempt to create standards for individual products, nor to set up specific testing and certification systems. The code recognizes that these activities fall under the sovereign rights of individual countries.

\section{Scope and Coverage}

In early Tokyo Round drafts of the code, the definition of "technical specification" followed International organization for Standardization (ISO) precedents by including PPMs and codes of practice. The United States supported full inclusion of PPMs in the code. In succeeding drafts, however, the term was redefined to exclude PPMs from the purview of most of the obligations of the code. This action was in response to the reluctance of some delegations to include them; as well as concerns over potential administrative burdens imposed by code application to agricultural products. (As indicated, PPMs are widely used in agricultural regulations.)

The code now covers only standards and technical regulations which apply to a product's final characteristics. While Article 14.25 of the code allows signatories to invoke dispute settlement procedures on PPM's under certain circumstances, narrow interpretations by the EC and some other signatories have severely limited their use.

4 The term "standards-related activity" applies to the development, adoption or application of any product standard, technical regulation, test method, or certification system.

5 The Member states of the European Community are Belgium, Denmark, France, Germany (F.R.), Greece, Ireland, Italy, Luxembourg, the Netherlands, Portugal, spain, and the United Kingdom.

6 The Member States of the European Free Trade Association (EFTA) are Austria, Finland, Iceland, Norway, Sweden and Switzerland. 
Code obligations are binding on central government bodies ("Parties") that have signed the Code. Parties must take "reasonable measures" to ensure that regional standardizing bodies of which they are members, as well as local government and nongovernmental bodies within their territories, comply with code obligations (except that local and non-governmental bodies are not obligated to notify the GATT of their proposed technical regulations or certification systems).

Standards code provisions are applicable to both agricultural and industrial products. They are not applicable to technical regulations or standards covering services, technical specifications included in government procurement contracts, nor standards established by private companies or industries for their own use.

The code includes provisions relating to the formulation and application of technical regulations, rules of certification systems and testing procedures. Other standards-related functions such as accreditation, product approval procedures, inspection procedures and quality assessment programs are among the areas currently being addressed in the Uruguay Round negotiations.

\section{Affected Manufacturing Sectors and Products}

PPMs are applicable to industries that produce and sell manufactured products or manufacturing processes and those industries that produce agricultural, mining or construction products. The industrial sectors identified in Table 2 are likely to be directly or indirectly affected by PPM's in standards or technical regulations.

The largely vertically integrated process-intensive market areas are often referred to as the "process control" industries and are comprised of such industrial sectors as:

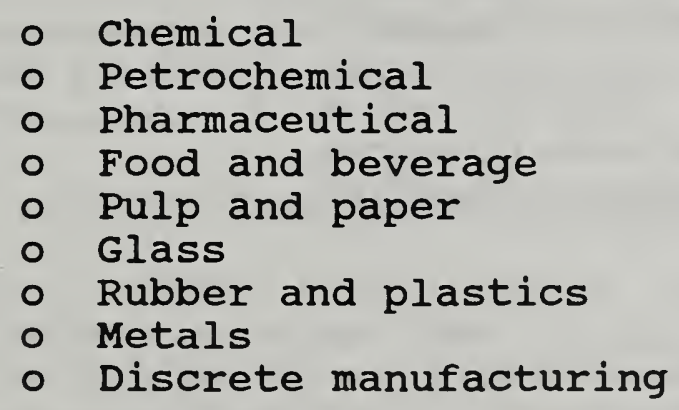

PPMs in these industries are characterized by a system or series of continuous or regularly occurring actions taking place in a predetermined or planned manner. Process controls - predominantly automatic - provide the ways and means by which conditions of. continuous production are automatically kept within desired values or within a required range. 


\section{Examples of PPM Type Standards}

The following are selected examples of PPM type standards: (These standards have not raised any known obstacles to trade.)

AWS C2.2-67- Recommended Practices for Metallizing with Aluminum and Zinc for Protection of Iron and steel

ASTM A 240 - Standard for Heat Resisting Steel Plates for Pressure Vessels

API 1104 - Standard for Welding Pipelines

NACE RP-01 - Surface Preparation of Steel Prior to coating

QQ-P-416 - Cadmium Plating

\section{Definitional Approaches for PPMs}

\section{Background}

The GATT Standards Code does not specifically define "product standard" or "PPM," but defers to definitions of such international standardizing bodies as the International organization for Standardization (ISO) and International Electrotechnical Commission (IEC). There are no readily available definitions or recognized references for "PPM." ISO/IEC Guide $2^{7}$ provides the following definition for "product standard" -

product standard: standard that specifies requirements to be fulfilled by a product or a group of products, to establish its fitness for purpose.

The term "fitness for purpose" is further defined ${ }^{8}$ -

fitness for purpose: Ability of a product, process or service to serve a defined purpose under specific conditions.

7 ISO/IEC Guide 2; "General Terms and Their Definitions concerning Standardization and Related Activities;" Fifth edition; 1986 ; p. 16 .

8 ibid, p. 6. 
The ISO/IEC Guide also provides a definition for the term "process standard"

process standard: standard that
specifies requirements to be
fulfilled by a process, to establish
its fitness for purpose.

A term often aligned to PPM is "code of practice" ${ }^{10}$, that ISO/IEC Guide 2 defines as follows:

$$
\begin{aligned}
& \text { code of practice: Document that } \\
& \text { recommends practices or procedures } \\
& \text { for the design, manufacture, } \\
& \text { installation, maintenance or } \\
& \text { utilization of equipment, structures } \\
& \text { or products. }
\end{aligned}
$$

For definitions of other Standards Code terms, see Appendix B, which reproduces Annex 1 of the Code - "Terms and Their Definitions for the Specific Purposes of This Agreement."

Product standards are generally understood to cover commodities and end-item manufactured goods. The provisions of a product standard are contained in a document which sets forth criteria for such product characteristics as: performance; levels of quality; class; kind; essential health and safety considerations; recommended design considerations and conditions. Product standards may include, or deal exclusively with other factors such as: terminology; sampling; symbols; testing and test methods; packaging, marking or labeling requirements as they apply to the final product. Testing for conformity takes place on the final product or commodity whether it has been processed or not. For regulated marketplaces or contractual arrangements, compliance is mandatory. Product standards may - and many times do - contain processing requirements. However, conformance to processing requirements is normally verified by inspection or test of the final product without abnormal disassembly, disjunction or further processing.

\section{NIST-Developed PPM Definition}

NIST drafted a definition to cover both industrial and nonindustrial product PPMs in August 1988. The NIST draft definition is in two parts -- first an explanation to characterize the term "processes and production methods," then using the term in the
9 ibid, p. 16.
10 ibid, p. 10 . 
context of a PPM standard. The current versions of the NIST draft definitions are as follows:

Processes and production method (PPM) One or more in a series of conditions or operations (e.g., mechanical, electrical, chemical, inspection, test) by means of which a material or product advances from one stage to another to its final state. PPMs include conditions and methods of growth, as well as controlled treatments, that subject materials or products to the influence of one or more types of physical or biological derived energy (e.g., mechanical, electrical, magnetic, chemical, thermal) as required to achieve a desired reaction, change, result or performance.

PPM standard (or PPM provisions within a product or process standard) A standard or provision that specifies the performance criteria of process and production methods to be employed in one or more stages in the design, manufacture, delivery, installation, treatment, or utilization of equipment, structures or products, or that specifies methods or conditions in accordance with which a product is to be grown or raised. Testing or certification of conformity with these methods, rather than of the characteristics of the final product, is required in conjunction with one or more steps in the process.

This definitional approach is intended to apply to all industrial and agricultural products from the raw material or commodity stage through all phases of production where PPM's may apply. The customary "fitness for purpose" characteristics are verified as they apply to the final product by such in-process conformance checks as inspection, test, certification, review, approval, etc.

In the first definition (i.e., for "process and production method" (PPM)) the word "process" itself may have to be added along with the terms "materials or products" because, in certain industrial sectors, "processes" such as plating, welding, heat treating, etc., are saleable items.

\section{Conclusions}

1. PPM's - either as self-contained standards or as specific provisions in product standards - may soon constitute a major segment of the standards universe and are generally more difficult to enforce as technical regulations. They are usually distinguished from those standards relating strictly to the 
uniformity or fitness for purpose of the final product. PPM's have been, and will likely continue to be, a basis for unnecessary nontariff trade barriers. When used in regulations, standards containing PPM provisions are likely to be more difficult to enforce than customary product standards or technical regulations. Sellers or exporting entities will have greater opportunity to deceive - or to pass off non-conforming products as acceptable - or even counterfeit products as compliant products -- as in the recent case of industrial fasteners and other products. Buyers and importing entities have more difficulty judging the acceptability of PPM characteristics than such criteria as dimensional uniformity needed for interchangeability, etc. Compared to such relatively simple PPM characteristics as weld strength or caloric content, final physical characteristics generally are more readily apparent, easily and acceptably measurable, and dimensional interchangeability quickly determinable.

2. While PPM's until recently have been mainly an agricultural issue, they are becoming widely used in industry. To an increasing extent, PPMs particularly in the pharmaceutical, medical device, food and biotechnology sectors are replacing product specifications in quality assurance programs in both the private and public sector.

3. Exclusion of PPM's from full GATT Standards code coverage has left Code signatories without a forum in which to challenge questionable or arbitrary manufacturing or process requirements, possibly fostering barriers to trade unjustified by health or safety considerations. Unjustifiable PPM's contravene the spirit of the code; it is in the interest of all parties to ensure that important benefits of the code -- transparency, consultation, and dispute settlement procedures, among others -- are not nullified by too narrow coverage or interpretation.

4. Bringing PPM's under full coverage of the GATT standards Code will certainly impose some additional administrative burdens on government regulatory bodies. Once the code is amended to cover PPM's, technical regulations expressed as PPMs -- e.g., bans on use of certain pesticides - - will come under the notification and consultation requirements and be subject to comment or challenge by other signatories under dispute settlement provisions. However, the greater discipline and transparency resulting from code coverage will ultimately benefit all parties. Regulations mandating obsolete process methods, for instance, may be used to protect uncompetitive local producers only at the economic cost of lost efficiency because competing technologies are blocked. Admitting PPM's to GATT discipline will advance the mutual acceptance of equivalent processes among signatories, thus allowing products to move more freely from country to country at various stages of the manufacturing process. 


\section{Recommendations}

1. We should seek a creative approach for resolving the PPM issue between the U.S. Government and EC positions in the GATT Standards Code Committee based on technical considerations. The U.S. should also encourage third countries to support a reasonable code change to further strengthen it while satisfying the needs of all Parties.

2. Where PPM's of trading partners differ, a mutually acceptable solution should be arranged based on the concept of equivalency, perhaps under the aegis of the GATT standards code. We should continue to support vigorously the GATT-accepted principle of promoting the adoption of performance-based criteria, rather than prescriptive characteristics, in technical regulations and standards. Prescriptive terminology for PPM's should be allowed only in those instances where it can be clearly shown that performance-based standards cannot be employed in health, safety and environmental regulation.

3. We should urge GATT standards code signatories to conduct a test program of required GATT notifications for proposed PPM-type technical regulations, as well as other technical regulations. A pilot study would help to assess the extent of trade-related PPM's, illuminate PPM issues, and expose administrative problems.

4. We should make U.S. producers who export industrial products more aware of the PPM issue and its possible impact on trade and regulation with trading partners. We should encourage U.S. exporters who experience trade difficulties related to PPM standards or regulations to inform the U.S. Government and seek assistance with specific problems.

The office of Standards code and Information at NIST should be prepared to respond accordingly. 
Table 1

GATT STANDARDS CODE SIGNATORIES

Argentina (a)

Austria

Belgium

Brazil (b)

Canada

Chile (b)

Czechoslovakia

Denmark

Egypt (b)

European Community (c)

Finland

France

Federal Republic of Germany

Greece (b)

Hong Kong

Hungary

India

Ireland

Italy

\author{
Japan \\ Korea \\ Luxembourg (b) \\ Mexico (b) \\ Netherlands \\ New Zealand \\ Norway \\ Pakistan (b) \\ Philippines \\ Portugal (b) \\ Romania \\ Rwanda (d) \\ Singapore \\ Spain \\ Sweden \\ Switzerland \\ Tunisia \\ United Kingdom \\ United States \\ Yugoslavia
}

(a) - the country has not yet ratified the standards code and has not reported any proposed regulations to the GATT secretariat.

(b) - the country has not reported any proposed regulations to the GATT Secretariat.

(c) - The European community is a signatory to all the GATT agreements. Individual European Community member states are signatories to the Standards Code and civil Aircraft Code as these Codes go beyond European Community authority.

(d) - the country has not established an inquiry point for standards information and has not reported any proposed regulations to the GATT Secretariat. 
Table 2

STANDARD INDUSTRIAL CLASSIFICATION (SIC) MAJOR GROUPINGS ${ }^{(a)}$

\begin{tabular}{|c|c|c|c|}
\hline SIC code & Sector & SIC code & Sector \\
\hline 01 & Agriculture - crops & 25 & Furniture \& fixtures \\
\hline 02 & Agriculture - livestock & 26 & $\begin{array}{l}\text { Paper \& allied } \\
\text { products }\end{array}$ \\
\hline 08 & Forestry & 27 & Printing \& publishing \\
\hline 09 & Fishing \& hunting & 28 & Chemicals \\
\hline 10 & Metal mining & 29 & Petroleum refining \\
\hline 12 & Coal mining & 30 & Rubber \& plastics \\
\hline 13 & oil \& gas extraction & 31 & $\begin{array}{l}\text { Leather \& leather } \\
\text { products }\end{array}$ \\
\hline 14 & Mineral quarrying & 32 & $\begin{array}{l}\text { stone/clay/glass/ } \\
\text { concrete products }\end{array}$ \\
\hline 15 & $\begin{array}{l}\text { General building } \\
\text { contractors }\end{array}$ & 33 & $\begin{array}{l}\text { Primary metal } \\
\text { industries }\end{array}$ \\
\hline 16 & $\begin{array}{l}\text { Heavy construction } \\
\text { contractors }\end{array}$ & 34 & $\begin{array}{l}\text { Fabricated metal } \\
\text { products }\end{array}$ \\
\hline 17 & Special trade contractors & 35 & $\begin{array}{l}\text { Machinery/computer } \\
\text { equipment }\end{array}$ \\
\hline 20 & Food products & 36 & $\begin{array}{l}\text { Electrical/electronic } \\
\text { equipment }\end{array}$ \\
\hline 21 & Tobacco products & 37 & $\begin{array}{l}\text { Transportation } \\
\text { equipment }\end{array}$ \\
\hline 22 & Textile mill products & 38 & $\begin{array}{l}\text { Instruments/clocks/ } \\
\text { optical goods }\end{array}$ \\
\hline 23 & Apparel & 39 & $\begin{array}{l}\text { Miscellaneous } \\
\text { manufacturing }\end{array}$ \\
\hline 24 & Lumber and wood products & & \\
\hline
\end{tabular}

(a) "Standard Industrial Classification Manual;" Executive office of the President, office of Management and Budget; 1987. 


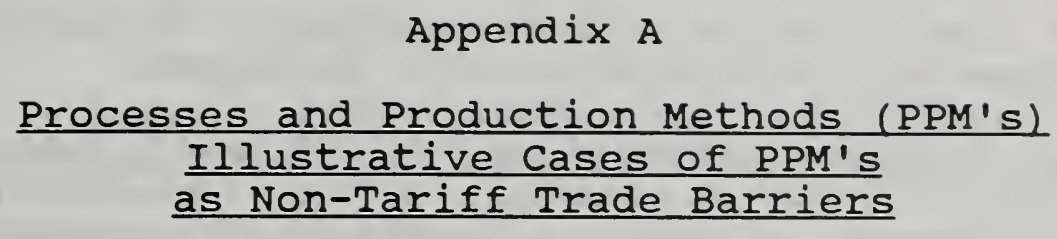

1. Singapore - Treatment of Timber and Plywood with Wood Preservatives

A U.S. firm encountered difficulties in 1986 in its efforts to market its wood preservative product in singapore. Two recognized methods of pressure treatment can achieve a specified level of protection for wood for a specified time duration, both using a chrome, copper and arsenic (CCA) compound either in a chemical salt or in an oxide formulation. While both formulations perform the same function, the oxide formulation is a concentrated form that requires less volume than chemical salt formulations to achieve the desired protection.

The applicable singapore standard" did not recognize the oxide formulation method nor provide a separate set of retention values for oxide treatment. Retention is important because an oxide needs less volume to achieve the same objective. The singapore standard made no provisions for this concentrated formulation requiring only salt to be used in a given volume for a given quantity of wood. Being concentrated, oxide is proportionately more expensive than salt and, pound for pound, cannot compete on price alone. However, when using the lesser amount of oxide needed to achieve the required protection, cost differences disappear and the oxide is competitive. The singapore market would be favorable to the U.S. firm's expansion plans, if the applicable standard recognized the chemical oxide method of treatment.

The cognizant SISIR Technical Committee responsible for revision of the applicable standard included several members affiliated with a British firm that manufactures and markets CCA salts in singapore. In addition, the committee chairman was a retired manager of the same British firm.

This is a clear case of a PPM being used in a product standard to specifically exclude a U.S. manufacturer's product, because it would compete effectively with favored domestic procedures.

11 Specification for Treatment of Timber and Plywood with Copper/Chrome/Arsenic Wood Preservatives, published by singapore Institute of standards and Industrial Research (SISIR), 1972. SISIR is a statutory governmental body under the Ministry of Finance in singapore and the member body to ISO. Singapore is a signatory to the GATT Standards code. 
2. Japan - Sterilization (Pasteurization) Procedures in the Manufacture of Non-Alcoholic Malt Beverages

Japanese law requires pasteurization of malt beverages at a temperature of $85^{\circ} \mathrm{C}$ for 30 minutes. A U.S. beverage producer has experienced frequent clearance problems by Japanese customs officials because they do not recognize the equivalency relationship for the pasteurization cycle of bottled or canned beverages processed in a tunnel pasteurizer during the packaging (i.e., bottling or canning) process. The Japanese criteria provide only for pasteurization in vats prior to bottling without recognizing the equivalent time-temperature curve and lethal rate curve $^{12}$ for packaged malt beverages processed through a conventional tunnel pasteurizer. Bottled or canned beverages are restricted from meeting the prescriptive Japanese criteria due to inevitable rupture of the packaging at elevated temperature.

The performance-based U.S. regulatory definition of pasteurization is as follows:

"Pasteurization of malt beverages means malt beverages which have been subjected to such process or processes in manufacture and packaging that in all cases all yeast cells or other microorganisms which could result in further fermentation or microbiological decomposition of the packaged malt beverages are killed, inactivated or removed."

To ensure effective pasteurization of malt beverages, it is necessary for the holding time, at a pasteurization temperature of $60^{\circ} \mathrm{C}$ to exceed 5.6 minutes. Other time-temperature combinations can be used as long as they fall directly on or to the right of the lethal rate curve. The effectiveness of any tunnel pasteurization process may be evaluated from information derived from the lethal rate curve for organisms in the particular beverage in question and the time-temperature curve of the coolest part of the package during the pasteurization process.

The U.S. producer has gained significant market share with the Japanese people but experiences periodic disruptions in clearing shipments through customs.

This case clearly points out the desirability of including appropriate performance-based provisions in PPM standards as opposed to prescriptive criteria which do not recognize all possible production methods.

12 Lethal rate curves disclose the time required for the destruction of a known concentration of specific organisms at a given temperature. 


\section{Appendix B \\ Terms and Their Definitions for the specific Purposes of this (GATT) Agreement}

Note: References to the definitions of international standardizing bodies in the explanatory notes are made as they were in effect in March 1979.

\section{Technical Specification}

A specification contained in a document which lays down characteristics of a product such as levels of quality, performance, safety or dimensions. It may include, or deal exclusively with terminology, symbols, testing and test methods, packaging, marking or labeling requirements as they apply to a product.

\section{Explanatory note:}

This agreement deals only with technical specifications relating to products. Thus the wording of the corresponding Economic Commission for Europe/International Organization for Standardization definition is amended in order to exclude services and codes of practice.

\section{Technical Regulation}

A technical specification, including the applicable administrative provisions, with which compliance is mandatory.

\section{Explanatory note:}

The wording differs from the corresponding Economic Commission for Europe International organization for Standardization definition because the latter is based on the definition of regulation which is not defined in this Agreement. Furthermore the Economic Commission for Europe/International organization for standardization definition contains a normative element which is included in the operative provisions of this Agreement. For the purposes of this Agreement, this definition covers also a standard of which the application has been made mandatory not by separate regulation but by virtue of a general law.

\section{Standard}

A technical specification approved by a recognized standardizing body for repeated or continuous application, with which compliance is not mandatory. 


\section{Explanatory note:}

The corresponding Economic Commission for Europe/International organization for standardization definition contains several normative elements which are not included in the above definition. Accordingly, technical specifications which are not based on consensus are covered by this Agreement. This definition does not cover technical specifications prepared by an individual company for its own production or consumption requirements. The word "body" covers also a national standardizing system.

4. International body or system

A body or system whose membership is open to the relevant bodies of at least all Parties to this Agreement.

5. Regional body or system

A body or system whose membership is open to the relevant bodies of only some of the parties.

6. Central government body

Central government, its ministries and departments or any body subject to the control of the central government in respect of the activity in question.

Explanatory note:

In the case of the European Economic community the provisions governing central government bodies apply. However, regional bodies or certification systems may be established within the European Economic Community, and in such cases would be subject to the provisions of this Agreement on regional bodies or certification systems.

7. Local government body

A government other than a central government (e.g. states, provinces, Lander, cantons, municipalities, etc.), its ministries or departments or any body subject to the control of such a government in respect of the activity in question.

8. Non-governmental body

A body other than a central government body or a local government body, including a non-governmental body which has legal power to enforce a technical regulation. 
9. Standardizing body

A governmental or non-governmental body, one of whose recognized activities is in the field of standardization.

10. International standard

A standard adopted by an international standardizing body.

Explanatory note:

The wording differs from the corresponding Economic Commission for Europe/International Organization for Standardization definition in order to make it consistent with other definitions of this Agreement. 


NIST-114A
(REV. 3-89)
NATIONAL INSTITUTE OF STANDARDS AND TECHNOLOGY
BIBLIOGRAPHIC DATA SHEET

1. PUBUCATION OR REPORT NUMBER

NISTIR 90-4265

2. PERFORMINO ORQANIZATION REPORT NUMBER

3. PUBUCATION DATE

MARCH 1990

4. TITLE AND SUBTITLE

Trade Implications of Processes and Production Methods (PPMs)

5. AUTHOR(S)

Patrick W. Cooke

6. PERFORMING ORGANIZATION (IF JOINT OR OTHER THAN NIST, SEE INSTRUCTIONS) U.S. DEPARTMEMT OF COMMERCE

MATIONAL INSTITUTE OF STANDARDS AND TECHNOLOQY

CANTHERSBURQ, MD 20899

7. CONTRACT/ORANT NUMBER

8. TYPE OF REPORT AND PERIOD COVERED

9. SPONSORINQ ORQANIZATION NAME AND COMPLETE ADDRESS (STREET, CITY, STATE, ZIP)

10. SUPPLEMENTARY NOTES

DOCUMENT DESCRIBES A COMPUTER PROGRAM; SF-185, FIPS SOFTWARE SUMMARY, IS ATTACHEO.

11. ABSTRACT (A 2OO-WORD OR LESS FACTUAL SUMMARY OF MOST SIGNIFICANT INFORMATION. IF DOCUMENT INCLUDES A SIONIFICANT BIBUOGRAPHY OR UTERATURE SURVEY, MENTION IT HERE.)

This report discusses processes and production methods (or PPM's) and their relationship to trade, the GATT Agreement on Technical Barriers to Trade, and traditional product standards used in international commerce. The report provides background information on PPM's, a suggested definition, and the possible extension of their application from the agricultural sector to industrial products.

12 KEY WORDS (6 TO 12 ENTRIES; ALPHABETICAL ORDER; CAPITALEE ONLY PAOPER MAMES; NHD SEPARATE KEY WORDS EY SEMICOLONS) definitions; GATT Standards Code; manufacturing; processes product standards; standardization; trade barriers

FON OFTICUL DISTRIBUTION. DO NOT RELEASE TO NATIONAL TECHNICAL INFORMATION SERVCE (NTIS).

ORDER FROM SUPERINTENDENT OF DOCUMENTS, U.S. GOVERNMENT PRINTINO OFFICE, WASHINOTON, DC 20402

14. MUMBEN OF PRINTED PAGES 23

15. PRICE

\section{A02}






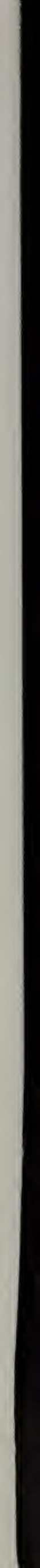

